\title{
Perjanjian Nominee sebagai Sarana Penguasaan Hak Milik atas Tanah oleh Warga Negara Asing (WNA) Menurut Kitab Undang-Undang Hukum Perdata
}

\author{
Yosia Hetharie \\ Fakultas Hukum Universitas Pattimura, Ambon, Indonesia \\ E-mail: josephushetharie@gmail.com
}

\begin{abstract}
The main issues of concern in this study is still the practice of control of land ownership by foreigners through a nominee agreement by using the guise of citizen so as if it did not violate the Act. This action was legalized by a notary / PPAT that in fact understand clearly applicable law. Therefore, this study aims to analyze the validity, binding strength, and as a result of the implementation of treaty law nominee in the control rights to land by foreigners based on the law of treaties Indonesia as well as the role and responsibilities of a notary / PPAT in issuing deeds nominee agreement. Based on the results of research conducted by the author, so in this study showed that the nominee agreement in terms of acquisition of land by foreigners to borrow the citizen name is not valid since the beginning of the holding no bad faith agreement of the parties, contrary to the principle of freedom of contract by not qualify objective the validity of an agreement as provided for in Article 1320 of the Civil Code, and contrary to Article 9, Article 21 paragraph (1), and reaffirmed by Article 26 paragraph (1) BAL. Therefore, not the validity of the nominee agreement, legally do not have binding force means the juridical consequences of their actual nominee agreement violates the law and therefore null and void and the land fell to the state as required in Article 26 paragraph (2) BAL. The role of the Notary/PPAT in issuing deeds relating to a nominee agreement must still be based on the applicable rules. If the deeds issued by the Notary/PPAT detrimental to the party, then the Notary/PPAT can be requested, with overall responsibility for the losses.
\end{abstract}

Keywords: Control Properties on the Ground, Nominee Agreement.

\section{A. PENDAHULUAN.}

Tanah merupakan salah satu komponen ekosistem yang sangat strategis bagi kelangsungan hidup umat manusia, dan juga sebagai faktor utama dalam setiap kegiatan pembangunan. Hubungan manusia dengan tanah yang kuat menuntut jaminan perlindungan hukum agar manusia dapat melaksanakan hak-haknya secara aman. 
Perwujudan pengaturan hubungan antara manusia dengan tanah, sebagai pelaksanaan Pasal 33 ayat (3) UUD NRI Tahun 1945 dengan dikeluarkannya Undang-Undang Nomor 5 Tahun 1960 Tentang Peraturan Dasar Pokok-Pokok Agraria, atau yang dikenal UndangUndang Pokok Agraria (selanjutnya disingkat UUPA).

UUPA menciptakan perubahan dalam hukum agraria nasional dengan menghapus dualisme hukum agraria yang tidak mencerminkan adanya kepastian hukum bagi rakyat Indonesia. Jaminan kepastian hukum dalam bidang agrarian, khususnya dalam bidang pertanahan menghendaki adanya kepastian tentang $:^{1}$

a. Hak atas tanahnya. Tanah yang dipunyai dengan hak milik, yang tidak terbatas jangka waktunya, harganya lebih tinggi daripada tanah sewa atau tanah hak guna bangunan.

b. Siapa yang mempunyai tanah. Ini mengenai subjek haknya, kepastian tentang hal ini diperlukan, karena perbuatan-perbuatan mengenai tanah tersebut pada asasnya hanya menimbulkan akibat hukum yang dikehendaki, jika dilakukan oleh pemiliknya.

c. Tanahnya. Ini mengenai objek haknya, yaitu dimana letaknya, berapa luasnya dan bagaimana batasbatasnya. Kiranya mudah dimengerti bahwa orang menginginkan kepastian juga mengenai hal-hal tersebut.

d. Hukumnya. Yaitu menyangkut aturan - aturan untuk mengetahui wewenang - wewenang dan kewajiban - kewajiban pemiliknya.

Menyangkut subjek yang dapat diberikan dan mempunyai hak atas tanah, maka sesuai dengan asas nasionalitas yang tercantum dalam UUPA, ditentukan dalam Pasal 9 ayat (1) yang menyatakan bahwa : “ Hanya Warga Negara Indonesia (WNI)

\footnotetext{
1 Harsono, Boedi. (2008). Hukum Agraria Indonesia : Sejarah Pembentukan Undang-
}

yang dapat mempunyai hubungan sepenuhnya dengan bumi, air, dan ruang angkasa".

Ketentuan yang mempertegas penjelasan Pasal 9 ayat (1) mengenai subjek penguasaan hak atas tanah tercantum dalam Pasal 21 UUPA yang menyatakan bahwa :

(1) Hanya warga negara Indonesia dapat mempunyai hak milik.

(2) Oleh Pemerintah ditetapkan badanbadan hukum yang dapat mempunyai hak milik dan syaratsyaratnya.

(3) Orang asing yang sesudah berlakunya undang-undang ini memperoleh hak milik karena pewarisan tanpa waktu atau percampuran harta karena perkawinan, demikian pula warga negara Indonesia yang mempunyai hak milik dan setelah berlakunya undang-undang ini kehilangan kewarganegaraannya, wajib melepaskan hak itu didalam jangka waktu satu tahun sejak diperolehnya hak tersebut atau hilang kewarganegaraan itu. Jika sesudah jangka waktu tersebut lampau hak milik itu tidak dilepaskan, maka hak tersebut hapus karena hukum dan tanahnya jatuh kepada negara, dengan ketentuan bahwa hak-hak pihak lain yang membebaninya tetap berlangsung.

(4) Selama seseorang di samping kewarganegaraan Indonesianya mempunyai kewarganegaraan asing, maka ia tidak dapat mempunyai tanah dengan hak milik dan baginya berlaku ketentuan dalam ayat 3 pasal ini.

Warga Negara Asing (selanjutnya disingkat WNA) yang masuk ke Indonesia, selain mempunyai tujuan wisata, juga berupaya menanamkan modal untuk usaha dengan menguasai tanah. Hal ini

Undang Pokok Agraria, Isi dan Pelaksanaannya, Jakarta: Djambatan, h. 50. 
terindikasi dengan banyaknya warga negara asing yang menguasai tanah di beberapa tempat di Indonesia, diantaranya di Provinsi Bali dan Daerah Istimewa Yogyakarta (DIY) sebagai daerah tujuan wisata di Indonesia.

Cara yang sering digunakan oleh WNA adalah dengan kedok melakukan jual beli tanah dengan perantaraan Warga Negara Indonesia (selanjutnya disingkat WNI) atau dengan kata lain atas nama WNI agar tidak menyalahi ketentuan hukum yang berlaku dalam UUPA. Tindakan ini yang dikenal sebagai nominee dengan maksud agar WNA dapat memiliki tanah secara absolut. Cara ini dikenal dengan nama nominee.

Perjanjian nominee antara WNA dan WNI terkait kepemilikan tanah ini, tidak dapat dilepas-pisahkan dari peran seorang Notaris / PPAT. Dalam prakteknya, kebanyakan WNA dan WNI menggunakan jasa seorang Notaris / PPAT untuk melegalkan perjanjian nominee dan membuat akta-akta yang dikehendaki oleh kedua belah pihak. Akta-akta yang dibuat oleh Notaris / PPAT tergantung kepada kesepakatan bersama dengan pertimbangan - pertimbangan yang disampaikan oleh Notaris / PPAT untuk memperkuat dan mengikat kedua belah pihak.

Berdasarkan uraian latar belakang di atas maka penulis tertarik untuk mengkaji permasalahan yang dikaji "Bagaimana keabsahan perjanjian nominee Menurut Kitab Undang-Undang Hukum Perdata, Bagaimana kekuatan mengikat perjanjian nominee dalam penguasaan hak milik atas tanah oleh warga negara asing, Bagaimana akibat hukum penguasaan hak milik atas tanah yang dilakukan oleh warga negara asing melalui perjanjian nominee, Bagaimana peran dan tanggung jawab Notaris/PPAT dalam mengeluarkan akta-akta melalui perjanjian nominee".

\section{B. METODE PENELITIAN}

Penelitian tentang “ Perjanjian
Nominee Sebagai Sarana Penguasaan Hak Milik Atas Tanah Oleh Warga Negara Asing Menurut Kitab Undang-Undang Hukum Perdata" merupakan penelitian normatif empiris, yaitu penelitian yang dilakukan dengan cara meneliti bahan hukum yang merupakan data sekunder atau disebut penelitian kepustakaan, kemudian untuk menunjang dan melengkapi data sekunder tersebut, maka dilakukan penelitian lapangan. Hasil penelitian ini dituangkan dalam bentuk laporan yang bersifat deskriptif analitis dengan menggunakan metode kualitatif.

Penelitian di lakukan di Daerah Istimewa Yogyakarta. Pemilihan lokasi penelitian Yogyakarta didasarkan pada pertimbangan penulis bahwa selain Bali yang merupakan daerah tujuan wisata yang paling sering dikunjungi oleh WNA, Yogyakarta juga menjadi daerah tujuan wisata yang sering pula dikunjungi oleh WNA. Selain itu, Penelitian semacam ini, belum pernah di lakukan oleh peneliti lain di Yogyakarta.

Penelitian ini Populasi yang penulis gunakan adalah Notaris/PPAT yang ada di Yogyakarta yaitu di Kabupaten Sleman dan Kota Yogyakarta. Teknik pengambilan sampel yang digunakan adalah non random sampling, yaitu suatu cara menentukan sampel dimata peneliti telah menentukan atau menunjuk sendiri sampel yang ingin diteliti dengan pertimbangan bahwa sampel yang diteli tersebut berhubungan langsung atau pernah menangani permasalahan yang ingin diteliti. Dari populasi yang ada, yang menjadi sampel bagi peneliti adalah 4 (empat) Notaris/PPAT yang terdiri dari 3 (tiga) Notaris/PPAT di Kota Yogyakarta, dan 1 (satu) Notaris/PPAT di Kabupaten Sleman. Dari keempat Notaris/PPAT ini, 3 (tiga) diantaranya pernah menangani permasalahan yang terkait dengan penelitian penulis, sedangkan 1 (satu) Notaris/PPAT Pernah bertemu dengan Klien yang ingin menggunakan jasanya tetapi di tolak.

Data secara umum terbagi dua, yaitu 
data primer dan data sekunder. Untuk data primer, alat pengumpul data yang digunakan berupa pedoman wawancara, yaitu mengajukan pertanyaan secara lisan baik kepada narasumber dengan cara tanya jawab yang dilakukan di lokasi penelitian.

Data sekunder, alat pengumpul data yang digunakan berupa studi pustaka. Adapun cara memperolehnya dengan cara mengumpulkan, mempelajari, menggali dan mengkaji dokumen-dokumen secara mendalam yang berkaitan dengan permasalahan yang diteliti.

\section{PEMBAHASAN}

\section{Keabsahan Perjanjian Nominee Menurut Kitab Undang-Undang Hukum Perdata}

Kata Perjanjian berasal dari Bahasa Inggris yakni contracts dan bahasa Belanda yakni overeenkomest, serta diatur dalam Pasal 1313 KUHPerdata yaitu: ${ }^{2}$

" Suatu perjanjian adalah suatu perbuatan dengan mana satu orang atau lebih mengikatkan dirinya terhadap satu orang lain atau lebih."

Menurut Subekti, bahwa Perjanjian adalah suatu peristiwa dimana seorang berjanji kepada seorang lain atau dimana dua orang itu saling berjanji untuk melaksanakan sesuatu hal. Dari peristiwa ini timbul suatu hubungan hukum antara dua pihak yang dinamakan perikatan. Dimana hubungan antara perjanjian dengan perikatan bahwa perjanjian menerbitkan perikatan. Perjanjian merupakan sumber terpenting yang melahirkan perikatan karena perikatan paling banyak diterbitkan oleh suatu perjanjian. $^{3}$

Perjanjian juga merupakan sumber hukum tanah nasional selain peraturan

2 Kie, Tan Tong. (2007). Studi Notaris dan Serba Serbi Praktek Notaris, Jakrta: Ichtiar Baru, h. 402 .

Sutarno. (2003), Aspek-Aspek Hukum perundang-undangan dan hukum adat serta hukum kebiasaan, dalam menyelesaikan kasus-kasus konkret, sudah barang tentu perjanjian yang diadakan oleh para pihak merupakan juga hukum bagi hubungan konkret yang bersangkutan (KUHPerdata Pasal 1338). Tetapi ada pembatasanya, yaitu khusus di bidang hukum tanah, sepanjang perjanjian yang diadakan itu tidak melanggar atau bertentangan dengan ketentuan UUPA.

Syarat sahnya suatu perjanjian diatur dalam Pasal 1320 KUHPerdata yaitu:

1) Sepakat mereka yang mengikatkan dirinya

2) Kecakapan untuk membuat suatu perikatan

3) Suatu hal tertentu

4) Suatu sebab yang halal

Dari 4 syarat tersebut, dapat dibedakan menjadi syarat subjektif, syarat ini apabila dilanggar maka perjanjian dapat dibatalkan, meliputi : ${ }^{4}$

1) Sepakat mereka yang mengikatkan dirinya

Syarat yang pertama sahnya perjanjian adalah adanya kesepakatan atau consensus para pihak. Kesepakatan ini diatur dalam Pasal 1320 ayat (1) KUHPerdata. Yang dimaksud dengan kesepakatan adalah persesuaian pernyataan kehendak antara satu orang atau lebih dengan pihak lainnya. Yang sesuai itu adalah pernyataan karena kehendak itu tidak dapat dilihat/diketahui orang lain. Sepakat yang merupakan salah satu syarat yang amat penting yang dapat ditandai oleh penawaran dan penerimaan dengan cara : tertulis, lisan, diam-diam, dan simbol simbol tertentu. Kesepakatan dengan tertulis, dapat dilakukan dengan akta otentik ataupun akta dibawah

Perkreditan pada Bank, Bandung: Alfabeta, h. 74.

4 Salim, Abdul. (2005), Hukum Bisnis Untuk Perusahaan, Jakarta: Prenada Media, h. 42. 
tangan. Terjadi kesepakatan berarti adanya kesesuaian, kecocokan, pertemuan kehendak dari yang mengadakan perjanjian atau pernyataan kehendak yang disetujui antara pihak-pihak. Unsur kesepakatan yaitu penawaran (offerte) adalah pernyataan pihak yang menawarkan dan penerimaan (acceptasi) adalah pernyataan pihak yang menerima penawaran. Jadi kesepakatan itu penting diketahui karena merupakan awal terjadinya perjanjiaan.

2) Kecakapan untuk membuat suatu perikatan

Dalam dunia hukum perkataan orang (person) berarti pendukung hak dan kewajiban yang juga disebut subyek hukum. Dengan demikian, maka dapat dikatakan bahwa setiap manusia baik WNI maupun WNA adalah pembawa hak (subyek hukum) yang memiliki hak dan kewajiban untuk melakukan perbuatan hukum. Meskipun setiap subyek hukum mempunyai hak dan kewajiban untuk melakukan perbuatan hukum, namun perbuatan hukum tersebut harus didukung oleh kecakapan dan kewenangan hukum. Kewenangan memiliki / menyandang hak dan kewajiban tersebut disebut kewenangan hukum atau kewenangan berhak, karena sejak lahir tidak semua subyek hukum (orang/person) yang ada pada umumnya memiliki kewenangan hukum itu, cakap atau dapat bertindak sendiri (bekwaamheid). Kecakapan berbuat adalah kewenangan untuk melakukan perbuatan - perbuatan hukum sendiri. Perbedaan antara kewenangan dengan kecakapan berbuat adalah bila kewenangan hukum maka subyek hukum dalam hal pasif sedang pada kecakapan berbuat maka subyek hukumnya pasif.

Syarat objektif, syarat ini apabila dilanggar maka perjanjiannya batal demi hukum, meliputi :

1) Suatu hal tertentu

Objek perjanjian adalah prestasi (pokok perjanjian). Prestasi adalah apa yang menjadi kewajiban debitur dan apa yang menjadi hak kreditur. Prestasi ini terdiri dari perbuatan positif dan negatif. Prestasi terdiri dari memberikan sesuatu berbuat sesuatu, dan tidak berbuat sesuatu (Pasal 1234 KUHPerdata)

2) Suatu kausa yang halal

Walaupun para pihak dapat membuat perjanjian apa saja, namun ada pengecualiannya yaitu sebuah perjanjian tidak boleh bertentangan dengan perundang-undangan, ketertiban umum, moral dan kesusilaan.

Sistem hukum Indonesia sama sekali tidak dikenal mengenai perjanjian nominee, sehingga dengan demikian tidak ada pengaturan secara khusus dan tegas mengenai perjanjian nominee ini. Dalam kamus hukum atau Black's Law Dictionary, arti dari nominee adalah : "One designated to act for another as his representative in a rather limited sense. It is used sometimes to signify an agent or trustee. It has no connotation, however, other than that of acting for another, in representation of another, or as the grantee of another." 5

Terjemahannya, seseorang ditunjuk bertindak atas pihak lain sebagai perwakilan dalam pengertian terbatas. Ini digunakan sewaktu - waktu untuk ditandatangani oleh agen atau orang kepercayaan. Tidak ada pengertian lain daripada hanya bertindak sebagai perwakilan pihak lain atau sebagai penjamin pihak lain.

Perjanjian nominee di bidang

5 Garner, Bryan A., Black's Law Dictionary, $\quad 8$ th ed, ( St.Paul, Minnesota, Thomson West h. 172. 
pertanahan dalam praktek adalah memberikan kemungkinan bagi WNA memiliki tanah yang dilarang UUPA adalah dengan jalan "Meminjam nama (Nominee)" WNI dalam melakukan jual beli, sehingga secara yuridis formal tidak menyalahi peraturan.

Akan tetapi jika ditelaah lebih lanjut mengenai Pasal 1320 KUHPerdata mengenai sahnya suatu perjanjian ayat (4) yang menyatakan bahwa "kausa yang halal" maka dilihat dari pasal 26 ayat (2) UUPA yang menyatakan bahwa : "Setiap jual-beli, penukaran, penghibahan, pemberian dengan wasiat dan perbuatanperbuatan lain yang dimaksudkan untuk langsung atau tidak langsung memindahkan hak milik kepada orang asing, kepada seorang warganegara yang di samping kewarganegaraan Indonesia mempunyai kewarganegaraan asing atau kepada suatu badan hukum, kecuali yang ditetapkan oleh Pemerintah termaksud dalam Pasal 21 ayat (2), adalah batal karena hukum dan tanahnya jatuh kepada Negara, dengan ketentuan, bahwa hak-hak pihak lain yang yang membebaninya tetap berlangsung serta semua pembayaran yang telah diterima oleh pemilik tidak dapat dituntut kembali". Maka perjanjian yang disepakati kedua belah pihak dengan sendirinya batal demi hukum dan sesuai dengan ketentuan pasal 26 UUPA tersebut maka tanahnya jatuh ketangan negara.

Selain syarat sahnya perjanjian yang keempat menyangkut kausa yang halal, jika melihat lagi tentang objek perjanjiannya yaitu tanah, tanah yang menjadi objek perjanjian ini akan menjadi objek yang terlarang ketika dipindahkan kepemilikannya dari WNI ke WNA melalui perjanjian nominee ini. Oleh karena itulah pelaksanaan perjanjian nominee dalam hal penguasaan hak milik atas tanah oleh WNA juga melanggar syarat sahnya perjanjian yang ketiga yaitu suatu hal tertentu.

Menurut hukum perjanjian Indonesia seseorang bebas untuk membuat perjanjian dengan pihak manapun yang dikehendakinya sebagaimana asas kebebasan berkontrak. Undang-undang hanya mengatur orang-orang tertentu yang tidak cakap untuk membuat perjanjian, pengaturan mengenai hal ini dapat dilihat dalam Pasal 1330 KUHPerdata. Dari ketentuan ini dapat disimpulkan bahwa setiap orang bebas untuk memilih pihak yang diinginkan untuk membuat perianjian, asalkan pihak tersebut bukan pihak yang tidak cakap.

Tetapi ada pembatasan terhadap asas kebebasan berkontrak tersebut. Salah satu pembatasan terhadap asas kebebasan berkontrak dapat dilihat dalam Pasal 1338 ayat (3) KUHPerdata yang menyatakan bahwa suatu perjanjian hanya dilaksanakan dengan itikad baik. Oleh karena itu para pihak tidak dapat menentukan sekehendak hatinya klausulklausul yang terdapat dalam perjanjiian tetapi harus didasarkan dan dilaksanakan dengan itikad baik. Perjanjian yang didasarkan pada itikad buruk misalnya penipuan mempunyai akibat hukum perjanjian tersebut dapat dibatalkan.

Perjanjian nominee ini, antara WNA dan WNI sejak awal disepakatinya perjanjian ada itikad buruk dari WNA untuk menyalahi ketentuan UUPA dengan maksud dapat memiliki dan menguasai tanah di Indonesia dengan hak milik. Itikad buruk ini muncul, ketika WNA dengan jelas mengetahui bahwa dalam ketentuan UUPA, ia tidak dapat memiliki dan menguasai tanah di Indonesia dengan hak milik, tetapi dengan cara yang tidak dibenarkan oleh undang-undang yaitu dengan kedok perjanjian nominee, WNA tersebut dapat memiliki dan menguasai tanah di Indonesia. itikad buruk dari WNA ini juga didukung oleh WNI yang dipinjamkan namanya tersebut karena alasan rekan kerja, teman, kenalan, juga karena ada imbalan materi dari WNA. Selain WNI, notaries / PPAT juga turut melegalkan perjanjian nominee dengan akta-kata yang dikeluarkan dalam perjanjian tersebut, padahal seorang notaries / PPAT tentunya mengetahui 
hukum dengan jelas.

\section{Kekuatan Mengikat Perjanjian Nominee Dalam Penguasaan Hak Milik Atas Tanah Oleh Warga Negara Asing (WNA)}

Kekuatan mengikat suatu perjanjian dapat ditemukan landasan hukumnya dalam bunyi Pasal 1338 ayat (1) KUHPerdata : "Semua perjanjian yang dibuat secara sah berlaku sebagai undangundang bagi mereka yang membuatnya"

Berdasarkan hasil penelitian, penulis menarik kesimpulan bahwa perjanjian nominee yang terjadi antara WNA dan WNI dalam hal kepemilikan tanah sebagai Hak Milik di Yogyakarta memiliki kekuatan mengikat, tetapi hanya mengikat kedua belah pihak sesuai dengan isi perjanjian yang telah di sepakati bersama dan dituangkan dalam akta-akta notariil. Hal ini dibuktikan dengan tidak pernah terjadi sengketa atau perbuatan yang dilakukan baik oleh WNA maupun WNI sekalipun yang melanggar isi perjanjian nominee ini. Artinya bahwa kedua belah pihak tunduk dan taat terhadap isi perjanjian nominee, sehingga perjanjian itu memiliki kekuatan mengikat bagi mereka. Perlu penulis tekankan sekali lagi bahwa kekuatan mengikat perjanjian nominee ini hanya terhadap kedua belah pihak jika tidak ada sengketa.

Pelaksanaan perjanjian nominee terlihat bahwa ketentuan mengenai syarat sahnya suatu perjanjian dilanggar adalah syarat objektif yaitu suatu hal tertentu (menyangkut obyek) dan kausa yang halal. Perjanjian nominee bertentangan dengan UUPA Pasal 26 ayat (2) yang merupakan salah satu batasan syarat kausa yang halal.

Dalam hukum perjanjian, syarat suatu hal tertentu dan kausa yang halal dikategorikan ke dalam syarat Objektif karena menyangkut obyek/bendanya. Suatu perjanjian yang tidak memenuhi syarat subjektif, maka perjanjian itu batal demi hukum atau batal dengan sendirinya (nietig van rechtswege). Konsekuensinya bagi perjanjian itu adalah perjanjian yang dilakukan dianggap tidak pernah ada. Kaitannya dengan perjanjian nominee adalah karena perjanjian nominee juga bertentangan dengan Pasal 26 ayat (2) UUPA maka akibatnya adalah perjanjian batal demi hukum dan dianggap tidak pernah ada.

Demikian dalam hal kekuatan mengikat dari perjanjian nominee secara kasat mata dalam prakteknya terlihat mengikat para pihak yang membuatnya, tetapi secara yuridis, jika sesungguhnya perjanjian nominee ini pada akhirnya batal demi hukum, maka seharusnya perjanjian tidak memiliki kekuatan mengikat, apalagi jika menimbulkan sengketa diantara para pihak.

\section{Akibat Hukum Penguasaan Hak Milik Atas Tanah Oleh Warga Negara Asing (WNA) Melalui Perjanjian Nominee}

Berdasarkan putusan Pengadilan Negeri Denpasar No. 796 / Pdt.G / 2012 / PN.Dps tertanggal 17 Oktober 2013 yang diperkuat dengan Putusan Pengadilan Tinggi Denpasar No. 12 / PDT / 2014 / PT.DPS tertanggal 23 April 2014 yang penulis gunakan sebagai bahan pertimbangan dan melengkapi analisis penulis ini, terlihat bahwa negara dalam hal ini pengadilan memutuskan bahwa perjanjian yang dimaksudkan baik langsung maupun tidak langsung mengalihkan hak milik atas tanah dari WNI kepada WNA adalah batal demi hukum. Hal tersebut mengandung konsekuensi bahwa perbuatan-perbuatan hukum tersebut dari awal memang tidak pernah ada, sehingga secara yuridis mengukuhkan pemilikan WNI atas tanah hak milik yang menjadi obyek perjanjian nominee tersebut.

Menurut penulis, apabila perbuatan hukum yang terkandung dalam perjanjian nominee dianggap batal demi hukum, yang mengandung konsekuensi bahwa perbuatan hukum itu tidak pernah ada 
yang membawa akibat tiadanya hak WNA atas tanah hak milik dalam perjanjian nominee tersebut. Seyogyanya akibat itu juga harus diberlakukan bagi WNI, sebab yang namanya tidak pernah ada, perbuatan hukum kedua belah pihak dianggap tidak ada. Dengan demikian, hak WNI atas tanah yang menjadi obyek dalam perjanjian nominee seyogyanya dianggap tidak pernah ada.

Sekalipun fakta hukum bahwa bukti pemilikan hak atas tanah (sertifikat) yang menjadi obyek perjanjian nominee atas nama WNI, yang secara yurudis formil WNI tersebut adalah pemiliknya menurut hemat penulis tidak serta merta kedudukan tersebut menjadi benar. Mengingat lahirnya sertifikat atas nama WNI tersebut diawali dengan adanya perjanjian nominee yang merupakan perbuatan melanggar hukum dan merupakan perbuatan diputuskan batal demi hukum sebagai konsekuensi yuridis sepantasnyalah pemilikan WNI terhadap tanah yang menjadi obyek perjanjian nominee itu juga dibatalkan.

Kaitannya dengan penguasaan tanah hak milik oleh WNA dengan menggunakan akta notaris/notariil dalam pembahasan ini adalah menelaah dan mengkaji keberadaan akta-akta (varian akta) tersebut sehubungan dengan larangan yang terkandung dalam Pasal 26 ayat (2) UUPA yang menentukan, bahwa :

"Setiap jual-beli, penukaran, penghibahan, pemberian dengan wasiat dan perbuatan-perbuatan lain yang dimaksudkan untuk langsung atau tidak langsung memindahkan hak milik kepada orang asing, kepada seorang warga Negara yang di samping kewarganegaraan Indonesianya mempunyai kewarganegaraan asing atau kepada suatu badan hukum, kecuali yang ditetapkan oleh Pemerintah termaksud dalam Pasal 21 ayat 2, adalah batal karena hukum dan tanahnya jatuh kepada Negara, dengan ketentuan, bahwa hak-hak pihak lain yang membebaninya tetap berlangsung serta semua pembayaran yang telah diterima oleh pemilik tidak dapat dituntut kembali".

Berdasarkan pada ketentuan di atas, keberadaan akta notaris yang di dalamnya mengandung adanya suatu perbuatanperbuatan hukum baik secara langsung ataupun tidak langsung mengakibatkan terjadinya peralihan hak milik atas tanah antara WNI dengan WNA, merupakan perbuatan melanggar hukum dan perbuatan-perbuatan tersebut batal demi hokum.

\section{Peran Dan Tanggung Jawab Notaris/PPAT Dalam Mengeluarkan Akta-Akta Sebagai Sarana Penguasaan Tanah Oleh Warga Negara Asing (WNA)}

Praktek penguasaan tanah dengan menggunakan perjanjian nominee, hal pertama yang mereka lakukan adalah membeli tanah, kemudian mereka mendatangi kantor Notaris/PPAT untuk membuat akta jual beli yang akan digunakan untuk membuat sertifikat tanah. Selain dengan penjual, orang asing yang membeli tanah tersebut juga didampingi oleh orang yang akan dipinjam namanya sebagai pemilik tanah pada sertifikat.

Dari hasil wawancara dengan seorang Notaris/PPAT tertanggal 22 November 2014, WNA yang pernah menjadi kliennya tersebut, ketika pertama kali menghadap dihadapannya dengan bersama WNI yang mau dipinjamkan namanya tersebut, oleh sang Notaris/PPAT sudah disarankan untuk menggunakan Hak Pakai dengan menjelaskan segala ketentuan tentang hak pakai. Oleh WNA disimpulkan bahwa dia tetap ingin menggunakan hak milik dengan jalan nominee ini. Alasan WNA tidak menggunakan Hak Pakai adalah karena adanya jangka waktu hak pakai. Namun jika menggunakan nominee maka WNA ini tidak akan lagi mempersoalkan 
ketentuan jangka waktu pakai.

Terkait dengan peran dan tanggung jawab notaris / PPAT, dalam Pasal 1 angka 1 UUJN memberikan definisi notaris sebagai berikut: "Notaris adalah pejabat umum yang berwenang membuat akta otentik dan kewenangan lainnya sebagaimana dimaksud dalam undangundang ini." Berdasarkan definisi tersebut dapat disimpulkan bahwa wewenang notaris sebagai pejabat umum membuat akta otentik yang secara tegas ditugaskan kepada mereka oleh undang-undang, sedangkan wewenang pejabat lain selain notaris merupakan pengecualian

Pemasalahan menyangkut apakah notaris dalam hal membuat akta otentik mengerti benar akan nilai dan akibatakibat dari pembuatan akta tersebut sebelum akhirnya akta tersebut dinyatakan cacat hukum. Dari hasil wawancara dengan Notaris / PPAT di Yogyakarta, penulis menyimpulkan seorang notaris yang akan membuat akta cenderung menganggap akta yang dibuatnya sudah sah apabila para pihak telah sepakat, dan masing-masing pihak cakap unyuk melakukan perbuatan hukum. Namun sering tidak diperhatikan terhadap obyek dan causa yang diperbolehkan. Meskipun disisi lain, Notaris / PPAT tersebut memahami mengenai larangan kepemilikan tanah oleh WNA berdasarkan UUPA.

Tidak ada kewajiban bagi notaries / PPAT untuk menyelidiki secara materiil mengenai hal-hal yang dikemukakan oleh para penghadap. Namun, tidak bertanggung jawabnya seorang notaris terhadap isi atau substansi akta yang dibuat, tidak seharusnya diartikan secara mutlak. Artinya meskipun substansi atau materi akta merupakan keinginan para pihak, tapi dalam memformulasikan keinginan atau permintaan para penghadap ke dalam bentuk akta, seorang notaris harus tetap berpijak pada aturan hukum yang berlaku. Hal ini penting untuk diingat agar jangan sampai kehendak para pihak tersebut merupakan kehendak yang dilarang atau melanggar aturan hukum, ketertiban, maupun kesusilaan. Karena pembuatan akta yang cacat hukum akan berakibat akta tersebut batal demi hukum.

Lahirnya tanggung jawab notaries / PPAT terhadap aktanya yang batal demi hukum, dapat digunakan teori pertanggungjawaban seperti, liability dan responbility. Liability merupakan karakter risiko atau tanggung gugat yang bergantung atau yang meliputi semua karakter hak dan kewajiban secara aktual atau potensial seperti kerugian, ancaman, kajahatan, biaya atau kondisi yang menciptakan tugas untuk melaksanakan undang - undang. Sedangkan responbility berarti hal yang dapat dipertanggungjawabkan atas suatu kewajiban, dan termasuk putusan, ketrampilan, kemampuan dan kecakapan meliputi juga kewajiban bertanggung jawab atas undang - undang yang dilaksanakan.

\section{P E N U T U P}

Perjanjian Nominee sebagai sarana penguasaan hak milik atas tanah yang dilakukan oleh WNA dengan jalan meminjam nama WNI untuk dicantumkan namanya pada sertifikat hak milik atas tanah bertentangan dengan asas itikad baik, tidak sesuai dengan asas kebebasan berkontrak karena bertentangan dengan undang-undang yaitu Pasal 9, Pasal 21 ayat (1), dan dipertegas dengan Pasal 26 ayat (1) UUPA, disamping itu juga tidak memenuhi syarat-syarat objektif sahnya suatu perjanjian sebagaimana yang disebutkan dalam Pasal 1320 KUHPerdata yaitu suatu hal tertentu (menyangkut objek perjanjian) dan syarat cuasa yang halal (syarat obyektif). Oleh karena itu perjanjian nominee dalam hal penguasaan hak milik atas tanah oleh WNA ini secara yuridis tidak sah.

Perjanjian Nominee dalam hal penguasaan hak milik atas tanah oleh WNA secara yuridis tidak sah, maka perjanjian ini tidak memiliki kekuatan 
mengikat.

Perjanjian nominee yang tidak memenuhi syarat obyektif menimbulkan akibat hukum yaitu perjanjian nominee tersebut batal demi hukum, dan dianggap dari awal tidak pernah ada perjanjian tersebut. hal yang sama juga tertuang di dalam Pasal 26 ayat (2) UUPA juga memberikan akibat hukum jika penguasaan hak milik atas tanah dikuasai oleh WNA maka perbuatan hukum tersebut batal demi hukum dan tanahnya jatuh kepada negara.

Akta yang dikeluarkan oleh notaris / PPAT haruslah memperhatikan ketentuan peraturan perundang-undangan yang berlaku sehingga isi dari akta tersebut tidak bertentangan dengan peraturan perundang-undangan. Dengan kata lain, seorang notaris / PPAT dalam mengeluarkan akta, perlu memperhatikan kebenaran materiil dari isi akta tersebut. Notaris / PPAT dalam hal mengeluarkan akta dan selanjutnya mengakibatkan kerugian kepada salah satu pihak terkait dengan akta tersebut, maka pihak yang dirugikan tersebut dapat meminta pertanggungjawaban dari notaris / PPAT yang bersangkutan. Dalam hal penguasaan hak milik atas tanah oleh WNA, ketika terjadi sengketa maka ada salah satu pihak yang dirugikan. Oleh karena itu, pihak yang merasa dirugikan, dapat meminta pertanggungjawaban dari notaris / PPAT yang mengeluarkan akta.

\section{DAFTAR PUSTAKA}

Salim, Abdul, (2005), Hukum Bisnis Untuk Perusahaan, Jakarta: Prenada Media.

Garner,Bryan A, Black's Law Dictionary, 8 th ed, ( St.Paul, Minnesota, Thomson West.

Harsono, Budi, (2008), Hukum Agraria Indonesia:Sejarah Pembentukan Undang-Undang Pokok Agraria, Isi dan Pelaksanaannya, Jakarta: Djambatan,
Istanto, Sugeng, (2007), Penelitian Hukum, Yogyakarta: Ganda.

Kie, Tan Tong, (2007), Studi Notaris dan Serba-Serbi Praktek Notaris, Jakarta: Ichtiar Baru.

Soekanto, Soerjono, (1983), Pengantar Penelitian Hukum, Jakarta: UI Press.

Soemitro, R.H, (1988), Metodelogi Penelitian Hukum dan Yurimetri, Jakarta: Ghalia Indonesia.

Sutarno, (2003), Aspek-Aspek Hukum Perkreditan pada Bank, Bandung: Alfabeta. 